ARTICLE

DOI: $10.1057 /$ s41599-018-0067-y

\title{
Populism between direct democracy and the technological myth
}

\author{
Emiliana De Blasio $^{1} \&$ Michele Sorice (iD ${ }^{1}$
}

\begin{abstract}
In recent years, the scientific debate on populism has experienced a new momentum: on the one hand, the emergence of new populisms even in Western democracies and on the other hand, disagreement among scholars on the definition of populism. In this context, new trends have emerged-such as those concerning the link between populism and technology-along with the need to revise the traditional study paradigms, which are often difficult to operationalise. The transformation of the political sphere appears to be strongly interconnected with the digital media landscape. If the new forms of communication are the cause or the effect of processes, such as the personalisation of leadership, the verticalisation of political organisations, the presidentialisation of political parties, or the social delegitimisation of the old "intermediate bodies", these forms should be the subject of ongoing research. At the same time, a very simplistic storyline tries to overlap the rise of neo-populist parties with their use of communication technologies. A quality that is common to the many different populisms is an appeal to the use of direct democracy as a tool to empower citizens. Populism itself is sometimes portrayed as almost synonymous with direct democracy. At the same time, direct democracy is used by populists as a critique of the lack of participation in representative democracy and the need to make it more participatory. In this perspective, technology becomes a tool (and a storyline) to facilitate the use of direct democracy and the rise of a new form of "hyper-representation". At the same time, concepts such as efficiency, privatisation, short-termism, newism, and meritocracy are keywords successfully used by populist leaders, technocracy élites and neo-liberal political leaders. In other words, we can highlight a strange meeting between technological storytelling about direct democracy and technocracy myths. Even among the new populist parties, the technopopulists appear to represent an important category, whose peculiarities can easily be put into evidence using some empirical tools (such as content analysis). The aim of this article is to investigate the relationships between technocracy, direct democracy's storytelling and hyper-representation as a distinctive characteristic of neo-populisms.
\end{abstract}

\footnotetext{
${ }^{1}$ Department of Political Sciences, LUISS University, Viale Romania, 32, 00197 Rome, RM, Italy. Correspondence and requests for materials should be addressed to E.D.B. (email: edeblasio@luiss.it) or to M.S. (email: msorice@luiss.it)
} 


\section{Introduction}

his article is predominantly theoretical, although some of the theoretical aspects presented here emerged from the early outcomes of long-term research into populism and populist parties in Europe. The analysis offered here is therefore supported by some empirical results, although they are not sufficient to describe and comprehensively analyse a complex set of phenomena such as that of new populisms.

The aim of this article is to illustrate the peculiarities of emerging populism in Italian political life. ${ }^{1}$ In particular, we have considered the most used definitions of populism: a) as a political communication style and/or a set of discursive practices (Taguieff, 2002; Jagers and Walgrave, 2007; Moffitt and Tormey, 2014); b) as a political strategy framed in certain types of organisation (Weyland, 2001; Betz, 2002; Kriesi, 2015); and c) as an ideology (Mudde, 2004; Kriesi and Pappas, 2015; van Kessel, 2015). At the same time, we propose using another approach that - even if it is compatible with other theoretical definitions-is based upon the concept of hyper-representation (Mastropaolo, 2016; Fasano et al., 2016). Using the outcomes from research on the major Italian political parties and their leaders, we have built a taxonomy of populisms in Italy; in particular, we have observed that aside from the most common "types" of populism (as they are referred to in the scientific literature), specific forms of populism, strongly related to the rhetoric on technology, are emerging. We have, in this case, used the concept of technopopulism; this is a typology of populism that shows areas overlapping with the political mediatisation processes.

The article first presents an account of the crisis of representation and its connection with the emerging trends in populist experiences; we then turn to the concept of populism as hyperrepresentation; we follow with a third section discussing the four types of populism as derived from our research on political parties and their leaders in Italy; we then conclude this work with a fourth section focused on technopopulism and its specific role in the Italian political scene (but also considering the emerging form of technopopulism in Europe).

\section{The crisis of representation}

Populisms-in the various and sometimes inevitably contradictory definitions-are often interpreted as responses to the lack of participation that distinguishes liberal representative democracies. This interpretation of the emergence of populisms and, with them, of so-called neo-populist parties is based on awareness of a crisis of representation (Mair, 2000; Papadopoulos, 2013; Sorice, 2014). Liberal democracy is, in fact, a "representative" democracy; historically centred on its electoral nature (though not immediately on the idea of universal suffrage or even on the concept of participation), it is based on a process of delegation. Representative democracy today presents four main characteristics: "(a) the sovereignty of the people expressed through the election of the representatives; (b) representation as a free-lance relationship; (c) an electoral mechanism that ensures a certain degree of responsibility towards the people by the representatives who speak and act in their name; (d) universal suffrage based on representation on political equality" (Urbinati, 2013a, p 89). Representative democracy, however, only works to avoid a contradiction between imperative mandate and free mandate (Sorice, 2014), so that the latter is tempered by some form of popular control. To achieve this difficult equilibrium, intermediate bodies are needed; it is only within the frame of these bodies that the debate and the legitimisation of public choices are possible. The political mandate, in other words, is unique and needs the input of political parties or similar social aggregations. However, what occurs if the parties lose their credibility and even the legitimacy of representation? In these cases, different trends emerge that are often summarised under the populist label. "Whenever a part of the 'people' or a whole people does not feel represented, in one way or another some sort of reaction comes back and it is named populism" (Revelli, 2017, p 3). It is also true that populism "is not a revolutionary movement because it does not create people's sovereignty but intervenes once people's sovereignty exists and its values and rules are written in a constitution. Populism represents an appeal to the people in a political order in which the people is formally already the sovereign" (Urbinati, 2013b, p 145). In other words, populism should be considered to be a mutation of representative democracy. ${ }^{2}$

The concept of representation is traditionally linked to two reference poles: on the one hand, the electoral dimension, on the other, the notion of participation. In fact, this connection is relatively recent and it finds its roots in the "democracy-election" linkage, which is, however, ideological. Bernard Manin (1995), for example, noted that contemporary democratic governments are the starting point for the evolution of a political system conceived to mitigate the "subversive" effects of democracy. This trend is also present in the development of the "electoral method" in the USA. James Madison, for instance, judged democracy as "a show full of troubles and disputes", destined for a quick and violent death (Madison, 1787). The same term "democracy" was used with suspicion; the conceptual overlap between a "republican" and a "democracy" choice is just a successful "storyline ", and it sounds ideological.

James Madison and Thomas Jefferson referred to substantial breakdowns between citizens and governors, wherein the latter should be able to represent the instances of all due to a type of superiority, a kind of "natural aristocracy", as Jefferson defined it (Dupuis-Déri, 2013). The elective method, in other words, developed at the dawn of "liberal democracies" as a system used to control power by economic oligarchies legitimised by popular vote (van Reybrouck, 2016). The key element of the elective method was, in fact, the recruitment of the political class; indeed, for Jefferson and Madison, the active electorate was open to all, the passive one was reserved for the "meritorious", a sort of "moral" élite that in fact coincided with the political and economic ruling classes.

The so-called "crisis of democracy" developed within the shortcircuit between the de-legitimisation of representative institutions (the intermediate bodies) and individuals' perception of a loss of power, as it appears mass political parties have guaranteed in the past. Peter Mair (2000), introducing the concept of "partyless democracy", perfectly identified one of the critical elements of liberal democracies. The progressive erosion of the long-term identities on which the party's legitimisation was founded has also put in crisis the established forms of political participation. The political party's crisis obviously has many causes; certainly, one very important cause is represented by the redefinition of those cleavages upon which traditional parties founded their own legitimacy and their collective identity. It is no coincidence that "high / low" or "centre / peripheral" fractures are more suitable today for explaining new social conflicts. ${ }^{3}$

Another critical element to consider is the crisis of public bureaucracies, which is one of the six variables that Yves Sintomer (2011) identifies as the structural causes of crises of democracies. The crisis of public bureaucracies, which has often contributed to social restraint, lies within the affirmation of New Public Management, which in Northern Europe has boosted the empowerment and growth of the state's efficiency towards citizens and in the rest of Europe has become the ideological shore of the strongest neo-liberal approaches: state-enterprise rhetoric (Crouch, 2003) or the idea of a light state has been a tool for the 
commodification of citizenship and for hastening the crisis of democratic institutions. In this regard, the political left also bears heavy responsibilities in several European crises: left and centreleft parties, in fact, valued and defended citizens as workers or wage-earners but not as users of services or persons with rights. At the same time, many parties within the socialist democratic tradition have a-critically accepted the rules of financial capitalism, heightening their own crisis of legitimacy. Furthermore, they thereby contribute, in fact, to the perception of a uniform political body that is easily stigmatised as "non-people" against which the "true" people could use anti-representational rhetoric. ${ }^{4}$

By contrast, Mény and Surel (2002, p 21) identified in the affirmation of populism the presence of a crisis of political intermediation, the process of personalising power and with it, the centrality of the media in political life.

\section{Populism as hyper-representation}

In this crisis of organised political representation, one of the ideological elements of neo-populist parties resides precisely in an attempt to delegitimise representation because they consider it to be exhausted by confronting the opportunities offered by "bottom-up" participation. In this framework, 'the people' is not conceived as aggregates of classes or social groups; it is, instead, defined as a homogenous mass opposing the "non-people" (Ionescu and Gellner, 1969; Weyland, 1999); the latter being, of course, primarily composed of politicians of any ideological position and subsequently by those who-rightly or wronglyare considered to be part of the power system managed by the "non-people".

Summarising, we can highlight some elements concerning the relationships between representation and populism.

1. Representation has been, historically, a legitimation of oligarchies through the electoral method and a device for reducing democratic participation.

2. Nevertheless, it has become an important tool in constitutional democracies to broaden the base of participation, thanks mainly to the role of mass parties.

3. The party's legitimacy crisis has created (along with other causes) a clear crisis of representation.

4. The re-emergence of "populist" claims and the emergence of neo-populist parties are responses to the representation deficit. This answer assumes a communication strategy of calling for "bottom-up participation" but it declines into the development of surrogate forms of representation, such as those defined as hyper-representation.

5. Hyper-representation can also be considered to be legitimised authoritarian leaderism, which can even assume forms of the populism of government. Elements of antisystem communicative rhetoric are paradoxically present even in some forms of this government type. Destabilised representation is a liberalised representation. Hyperrepresentation is based on the hyper-pluralism of modern societies and, at the same time, it fuels it, also thanks to the media. If the hypo-representation of politics (the absence of institutionalised politics due to the crisis of political parties as intermediate bodies) promotes personalisation, hyperrepresentation is a kind of fragmentation and dispersion of the people that is reconstituted into "unity" thanks to the "discourse" of populisms (Moffitt and Tormey, 2014). ${ }^{5}$

6. The emphasis on participation usually runs out in the plebiscitary appeal to legitimise the leader (supreme representative of the people) against all others (the nonpeople).

7. Reference to the most articulated forms of participatory and deliberative democracy is present in only some trends within social populism that are historically connected to the antiestablishment, but not anti-system, position of the radical left or instances of social movements (from those against austerity to those who can be placed in the "rebel by doing" group) (De Blasio and Sorice, 2014).

In many cases, the emphasis on bottom-up participation is mostly reduced to (a) an emphasis on direct democracy; (b) a legitimation of authoritarian leaderships, where the "leader" becomes the "supreme representative" of popular interests; or (c) the phenomena of ethnotribalism, a tactical tool for building an "us" against "them" tendency that enhances the popular identity against the "non-people" composed of minoritarian élites. A variation of authoritarian leadership, however, is represented by politicians who define themselves as "new": this constitutes an example of "top-down populism" or "governmental populism" (Revelli, 2017, p 26). The outcomes of the highly emphasised "bottom-up participation" are not merely the development of claims for representation (Saward 2010) but also shift towards the radical de-structuring of the same representation in favour of what can be effectively defined as hyper-representation (Mastropaolo, 2016). ${ }^{6}$

Figure 1 shows schematically the shifting from representation to hyper-representation.

The same rhetoric on direct democracy tends to restore a principle of aggregation (as in Madison's conceptions of the representative method); it is no coincidence that populist movements and parties tend to reject the logic of participatory democracy or the methods of deliberation. This logic is sometimes rejected due to the presumed efficiency of technologies for the improvement of democracy. Considering the continuous and responsible participation of everyone, these movements prefer the episodic and decisive exercise of the referendum (the use of judicial or electoral instruments within representative democracies). Considering the endogenous dimension (della Porta, 2013) of democratic processes, they prefer the exogenous dimension that is born and exhausted in the aggregative logic of the vote or the plebiscite.

Following Donatella della Porta's analysis of democracy, Table 1 shows the four types of democracy as they emerge from the cross between decision methods (majoritarian vote or deliberation) and the political process (delegation or participation). While direct democracy can be framed in the first chart corner, deliberativeparticipatory democracy is based upon the logic of inclusiveness and the idea of citizenship as knowledge.

We should still emphasise that the concept of citizenship constitutes one the backgrounds, simultaneously, of liberal democracies, of the aggregative structure of direct democracy and of some populist rhetoric.

It is not casualty that the populist appeal looks for legitimation in the concept of citizenship as status (in Italy: "Prima gli italiani!" The Italians First, in the UK: "The English first!", in TicinoSwitzerland: "Prima i nostril" Ours first).") In these cases, citizenship is ascriptive: in many cases, representative democracy and direct democracy are both anchored to the idea of citizenship as status; this is also the background in which the neo-liberal ideology is rooted (Mastropaolo, 2000).

Another perspective is represented by the concept of citizenship as a body of civic knowledge, a sort of social frame in which participation in decision-making processes is a social right. The logic of inclusiveness - which is at the base of the idea of citizenship as civic knowledge-also represents a tool to improve the quality of democracy towards a participatory style. In other words, the concept of citizenship as status links together the emphasis on direct democracy and some important aspects of populist rhetoric. Here, the inclusiveness of people having civic 


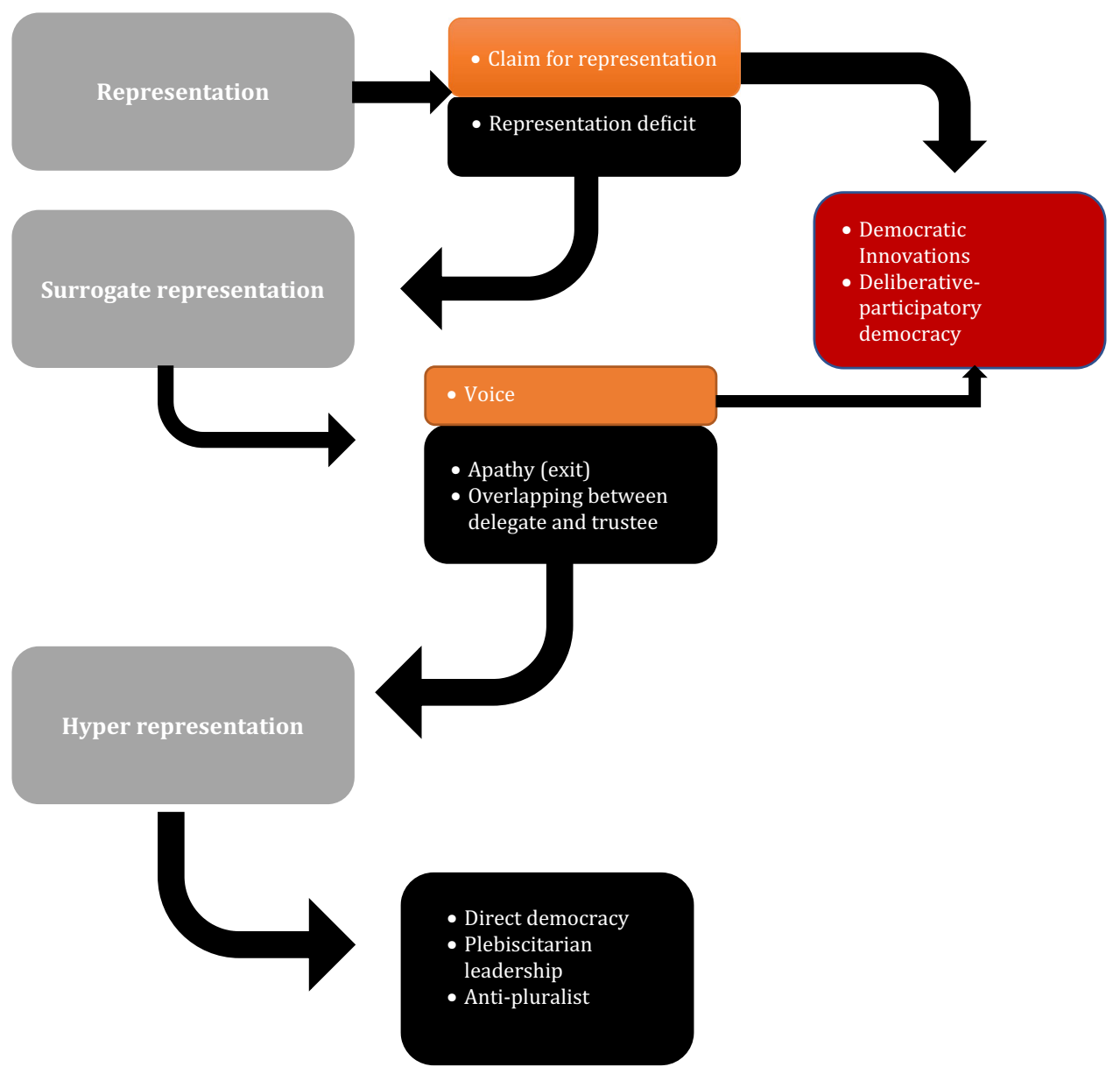

Fig. 1 Hyper representation. Source: The Authors

Table 1 Four types of democracy and the place of direct democracy

\begin{tabular}{|c|c|c|}
\hline & Majoritarian Vote & Deliberation \\
\hline $\begin{array}{c}\text { Delegation } \\
\text { (exogenous identities) }\end{array}$ & Liberal democracy & $\begin{array}{c}\text { Liberal deliberative } \\
\text { democracy }\end{array}$ \\
\cline { 2 - 3 } $\begin{array}{c}\text { Participation } \\
\text { (endogenous identities) }\end{array}$ & Participatory democracy & $\begin{array}{c}\text { Deliberative-participatory } \\
\text { democracy }\end{array}$ \\
\hline Direct democracy & \\
& $\begin{array}{l}\text { Participatory democracy is legitimised } \\
\text { by inclusiveness } \\
\text { Citizenship as civic knowledge }\end{array}$ \\
\hline
\end{tabular}

Source: Della Porta (2013) with modifications

knowledge constitutes the basic point of reference for affiliative citizenship. In this perspective, participatory democracy can represent a sort of counter-hegemonic tool; the idea of participation in decision-making processes as a social right is, in fact, one of the key concepts used by left-wing political parties.

Other scholars have highlighted the relationships between populism and the need for participation. Cas Mudde, for example, highlights the gap between participation and populism: "The heartland of contemporary populism is focused primarily on the output and not on the input of democracy"7 (Mudde, 2015). Even the centrality of the leader (also in popular imagination) appears to be in support of Mudde's thesis. However, we can also refer to the concept of claims of representation, which often involve multiple and sometimes overlapping audiences; there can 
be differences between intended and actual audiences. The notion of the audience (as it emerges from the tradition of audience and cultural studies) is crucial to representation and much neglected in studies of representation (Saward, 2010). Most likely, we could also consider populism as a peculiar form of audience representation. In this sense, the concept of hyper-representation can effectively be used to coherently connect some of the empirical evidence emerging from the analysis of populist leader discourses and political party manifestos.

\section{Our research}

The aim of our research is to better define some theoretical questions about populism, starting from three research questions:

RQ1. How can populism be measured? How can a "taxonomy" of populism be defined?

RQ2. Do populist and non-populist political parties adopt a populist communication style? Do they use specific topics?

RQ3. Which communication styles do leaders use and which features characterise each style? Does the operationalisation of the populist communication style fit the ideological indicators emerging in the literature?

In our research, we have combined three methods. With the first two methods, we have-de facto-replicated the measurement of populism as proposed and achieved by Teun Pauwels (2014) in his study on populism in Belgium, Germany and the Netherlands. We have used, in other words, a simple classification through minimal definition (i.e., analysing whether a party matches all minimal criteria to be labelled populist) and a content analysis of party and election manifestos.

Additionally, our summary codebook is very similar to that used by Pauwels; it starts from three interrelated characteristics that constitute the background of populisms: (a) populism emphasising the role and centrality of the "people"; (b) populism as an anti-elitist position and (c) populism as an exclusionary ideology (based on the rhetoric of "us"- the people-against "them"-the "others"-conceived as an indistinct entity). The analysis of party manifestos has been conducted using content analysis, assuming that the manifestos can be considered to be outputs of populism as a type of thin-centred ideology (Mair and Mudde, 1998; Mudde, 2000; Pauwels, 2014) and a "political style" (Moffitt and Tormey, 2014). In this case, we have used a specific type of content analysis and, in particular, evaluative assertion analysis. The basic idea behind this technique is that language is never neutral and that therefore it always produces a possible interpretation of the attitude of the source (Pauwels, 2014). If this is true, then it is always possible to assess the position and/or attitude of the author of the text under analysis; such evaluation is dichotomous (favourable/opposite, likes/dislikes, positive/negative, to be shared/to be rejected, etc.). The dichotomous assessment is clearly a reduction in complexity (a hyper-simplification, perhaps even a trivialisation); at the same time, however, it allows easier classification.

To evaluate assertions, we first had to identify the objects of the attitudes present in the text (or in the corpus) under study, selecting those relevant to the research. Next, we identified the assertions associated with the objects of the previously selected attitude. At this point, it was useful to try to reduce the complexity of the evaluation assertions (in some cases, they can be very complex, but they will certainly be less complex in political discourses with strong demagogic connotations). Only after completing these preliminary tasks did it become possible to carry out a detailed analysis of the texts. To do this, we needed to: (a) assign a value to the components of every assertion (we needed to measure the semantic differential) and then (b) calculate the resulting scores. This last step allowed us to create an evaluation

\section{Table 2 Anti-political rhetoric}

\section{Anti-political rhetoric}

\section{Against}

Anti-system rhetoric

Anti-state rhetoric

Anti-party rhetoric

Anti-intellectual rhetoric Intellectuals, professors

Source: Sorice (2014)

index. The evaluation of assertions is useful for analysing political language. It is also useful for studying semantic evaluation differentials; in this case, we had to score both the evaluative assertions and those ones referred to as "connectors" (the scores can be negative, positive or neutral). Examples of evaluative assertions are expressions such as "partito dell'odio" (party of hatred) "comunisti mangia-bambini" (communist children eaters), "Italia del fare" (Italy of doing) and so on. To measure the assertions, a very simple formula is commonly used, which we state as follows:

$$
V_{i}=\frac{\sum_{e t}^{n} e t_{n} \cdot c_{n}}{\sum_{c=1}^{n} c_{n}}
$$

where $V$ is the average level of evaluation in the $n$ themes of type $i$, et represents the terms of evaluation, and $c$ is the score we attribute to the verbal connections.

A third method concerns the analysis of leaders' official discourse and official documents, which are investigated using a simplified frame analysis. All documents were retrieved from official sources in their entirety. We performed a first round of manual coding, applying a frame analysis to the official documents to build the codebook following a grounded approach and to identify the whole spectrum of issues that they cover. The frame analysis method allowed us to distinguish between measures (i.e., specific proposals, pieces of legislation, etc.), which we treated as footings, and the motivations for adopting them, or frames; in particular, we found three possible frames: economic constraints or opportunities, questions concerning securitisation and the enhancement of democracy. ${ }^{8}$

We also found a relationship between anti-political rhetoric as defined by Michele Sorice (2014) and the discursive arguments presented in the parties' manifestos.

The adoption of anti-political rhetoric appears to be a distinctive characteristic of populism; the four rhetorical styles tend to emphasise exclusionary populism. Anti-politics is only a populist rhetoric that feeds on the clash between "us" and "them"; it thus adopts a mechanism of ideological unification. In other words, anti-politics is absolutely ideological, even when it adopts discursive strategies against party "ideologies" (Table 2).

We can define the first principle as rhetoric against the system; it is perhaps one of the most common forms of political language, and not only within recent decades. In this type of rhetoric, the "enemy" is the institutional system and/or the way in which the state itself is organised. This rhetoric uses a kind of language and specific grammar that characterise the forms of populism that do not recognise the legitimacy of the institutional structure. Usually, it is the party system (and/or the way it is organised) that is blamed, in reference to an analysis (it does not matter if presumed or real) of its structural weaknesses and inability to produce lasting (or strong) governments. 
The second type of anti-political rhetoric is anti-state rhetoric. For the most part, the welfare system comes under attack from this type of rhetoric. Its main targets are the state, which it accuses of being "nosy" and of seeking to meddle even in the private life of its citizens; the government, usually accused of being too intrusive and in constant search of new and more sophisticated forms of taxation; and public officials with judicial powers (magistrates), who, particularly in Italy, have been publicly and vehemently blamed by many centre-right politicians for some of the country's shortcomings (the slowness of the justice system, the ease with which criminals are released, the ostensible links between justice and politics). This anti-political rhetoric embraces cultural and political spheres that in other respects are miles apart; the Lega Nord's criticism of centralised government (clearly evoked by the expression "Roma ladrona"-thieving Rome) has much in common with propaganda against the "tax collector state" (and, in general, against the state's supposed excessive meddling in the lives of its citizens) voiced by the champions of an ultra-liberal approach to the economy and the organisation of society. Anti-political rhetoric relies on a small number of key concepts: (a) "making one's own decisions about one's future", that "future" being either personal (as a member of society) or collective (as the "North" or the "South"); (b) a moral obligation "not to pay others to squander resources", "squander resources" including the costs of the national health system and costs to the environment; (c) the advantages of the state as a "neutral" and "distant" regulator; (d) the need for "few laws" that are organised above all to prevent the judiciary (accused of being "slow", "bureaucratic" or "partisan") from enjoying "too much" freedom of action; and (e) attacking the inefficiency of the justice system, which allegedly provides too many "safeguards" for those suspected or accused of various offences (politicised justice). Some political parties often strategically combine slogans that are fundamentally "anti-safeguard" and de facto in favour of politicised justice, with political rhetoric in which the judiciary is accused of being permissive. Contrary to appearances, this is not a schizophrenic message: it is a clear populist strategy that stigmatises the judiciary for the "otherness" that sets it apart from the people, with the judge characterised as someone "other" than us. Therefore, we have "us" (the people) on one side and "them" (the judiciary) on the other in the role of "persecutor" or "defender of criminals" according to circumstances. ${ }^{9}$

The third form of anti-political rhetoric is anti-party. In reality, the target of this type of rhetoric is not just political parties but the whole political system organised around parties and political movements. In other words, without becoming explicitly antisystem, this rhetoric often borrows some anti-system content and expressions. Anti-party rhetoric is fuelled by a strong aversion to "professional" politicians, who are accused of being unaware of the real needs of the "people". The political "caste"10 thus becomes another group of "them" against "us". This anti-party rhetoric serves to launch a new kind of politician who presents himself/ herself as a receptacle for the popular "us" to be set against the "them" of "Italy's old political class" (using the same words Silvio Berlusconi used in his televised discourse of January 1994, when he presented himself as leader of a new political party). Anti-party rhetoric addresses mainly (though not exclusively) television viewers and is greatly aided in this by the progressive popularisation of politics (Mazzoleni and Sfardini, 2010). Silvio Berlusconi is emblematic of the telepopulist leader (Taguieff, 2002) who builds his diversification strategy with the help of television and simultaneously constantly re-asserts his "newism". Similarly, since 2013, Matteo Renzi has been focusing his attention on communication technology to assert his "newism" as a "scrapper". In the same frame, Beppe Grillo, comedian, blogger, and above, influential leader of the MoVimento 5 Stelle (Five Star Movement or
M5S), describes professional "politicians" as aliens with no links to Italian society, and the proposal for online direct democracy is presented as a tool to marginalise the "old" political parties. Here, the populace is not an aggregation of classes or social groups; it is a homogeneous mass ${ }^{11}$ that opposes the "non-people" (consisting in this case of politicians, regardless of ideology or institutional position).

The fourth type of anti-political rhetoric is anti-intellectual. It is not new in the Italian political scene (and indeed also exists outside Italy ${ }^{12}$ ). Once again, the conflict is between the popular "us"-consisting of those who perform manual jobs and make hardnosed "realistic" lifestyle choices—and "them", the professors (or "upstart academics") as well as public sector employees likened to intellectuals because they are also incapable of hardnosed realism (and are essentially "slackers"). While the rhetoric against "so-called culture" dates back to 1949, when the expression "culturame" was first used at the Christian Democrats' party conference in Venice by Mario Scelba to attack intellectuals from the opposing political camp, ${ }^{13}$ the tactic of demonising culture and intellectuals peaked during the 2009-2011 period with a comeback in Matteo Renzi's leadership of the Democratic Party and Matteo Salvini's leadership of the Northern League. This rhetoric returned during the campaign for the "constitutional referendum" of 2016: the many academics deployed against the proposed constitutional reform (defeated in the referendum vote) were labelled by many leaders of the Democratic Party as "professoroni" (a fundamentally derogatory and derisive term). Antiintellectual rhetoric relied on the development of a new media hegemony that Massimiliano Panarari (2010) has appropriately termed a sub-cultural hegemony. The de-legitimisation of intellectual work is ideological. It tends to sideline argumentation in favour of shouting spectacles, replacing the principle of authority with the "principle of majority".

\section{Four types of populism}

The rhetoric of bottom-up participation hides the temptation of "leaderism"14 on one side and the push for hyper-representation on the other. What emerges from the analysis of posters, the programmes of political parties and the public speeches of populist party leaders in the Italian public sphere is a very peculiar picture. In this study, we have tried to identify the different types of populism and their main characteristics. Adopting an approach based on content analysis-and substantially replicating that used by Teun Pauwels (2014) in his influential study on populism in Belgium, Germany and the Netherlands-we have identified four predominant types of populism in Italy. ${ }^{15}$ These types are also useful to frame and position the Italian populist parties. The four types (neo-liberal populism, social populism, national populism, and technopopulism) have several common characteristics (see Table 3). Among these, we can observe an emphasis on the value of direct democracy and the emergence of hyper-representation logic (albeit with different forms) with the (significant) exception of social (or democratic ${ }^{16}$ ) populism, in which only areas of the radical left and antagonistic social movements are located. It is no coincidence that only the latter segment explicitly refers to participatory democracy, clearly identified as an alternative to liberal democracy and conveniently cut from direct democracy (on parties and movements against austerity, see della Porta et al., 2017). It should also be noted that in this area, the anti-establishment rhetoric almost completely replaces the anti-system position (typical, for example, of the right-wing and ethnic populisms). It is useful, here, to highlight that the radical left ${ }^{17}$ - across Europe and especially in Italy-is characterised by a strong anti-establishment position, but it is not anti-system (Damiani, 2017). 


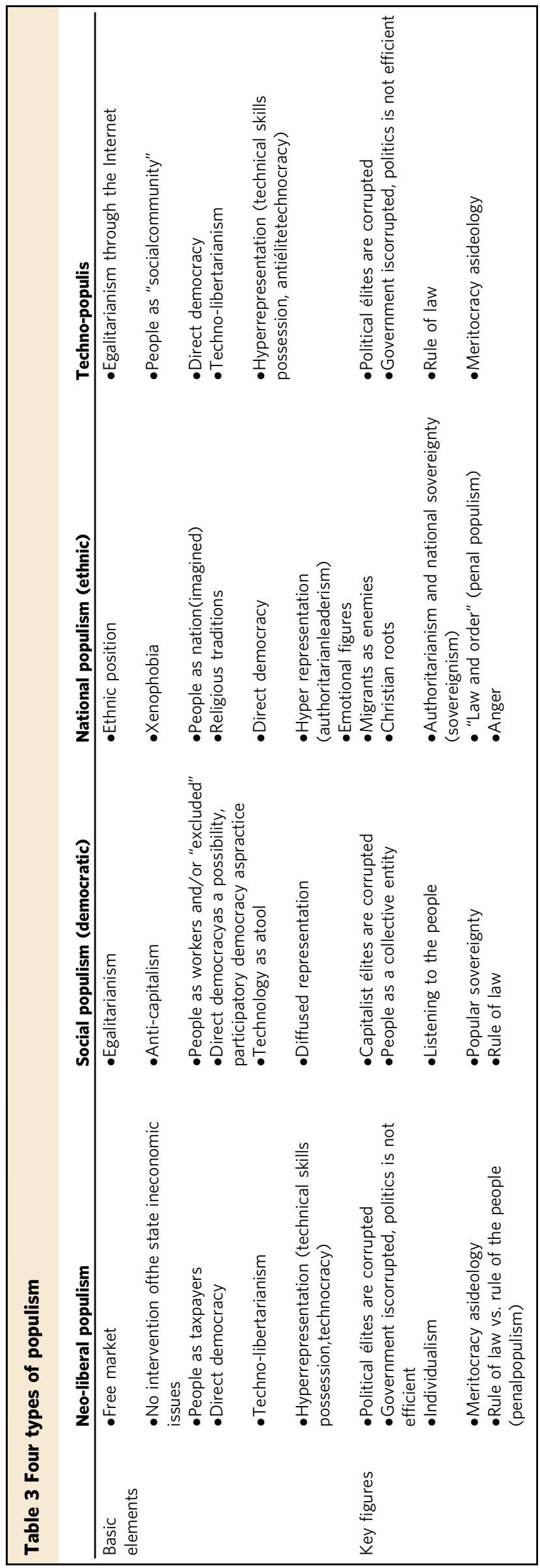

Table 3 shows the basic elements and the key figures as they emerged from our study of party and electoral manifestos. We must underline some relevant aspects. Among the key figures, for example, we noted the insurgence of two types of penal populism (Anastasia et al., 2015); the first type is based on the clash between the rule of law and the "rule of the people", and the second type is framed in a conservative rhetoric of "law and order". All four populisms include concern with the corruption of the élites and/or the government and belief in the lack of efficiency of politicians. In addition, if "individualism" constitutes a key facet in neo-liberal populism, it is replaced by networked individualism within the optimistic perspective of technopopulism. Another key figure to emphasise is meritocracy, a loaded and controversial term that is often used in an ideological manner. As Jo Littler stated in 2013, "we should pay close attention to meritocracy because it has become a key ideological means by which plutocracy-or government by a wealthy élite-perpetuates itself through neo-liberal culture. It is not, in other words, merely a coincidence that the common idea that we live, or should live, in a meritocratic age co-exists with a pronounced lack of social mobility and the continuation of vested hereditary economic interests" (see also Littler, 2018). We have found the word "meritocracy" and the semantic constellation of related terms in almost all political programmes and party manifestos.

A great number of papers and research reports have been dedicated to the analysis of sovereignist populism, its relationship with the concept of national community and, in general, to the exclusionary populism launched and supported by the new rightwing parties. Even if the anti-system perspective can be mutually implemented by right and left parties, we have noted a discursive difference between left-wing parties and right-wing parties regarding the concept of sovereignty. Left-wing parties (those that can be inserted into the social populism area) define sovereignty as constitutional popular control, while right-wing parties (and especially far-right movements and parties) translate sovereignty into an exclusionary sovereignism. We have found some similarities between exclusionary populism and what we have called national/ethnic populism

The logic of "us vs. them" is common in the populists' appeal, and it has been used as an indicator to define the same conception of populism. In this perspective, we can use the Weyland's conception of populism. Having presented the "people" as the "losers" of modernisation, he identifies the "élites" with the old political class. Indeed, populist supporters consider oligarchies as the exploiters who have caused their present woes. Therefore, strong attacks against the perceived (or existing) oligarchy have a double function: they enhance the populist leader's authoritarian face to his or her electors while at the same time, they contribute to eroding the opponents' legitimacy. The individuation of a political enemy is necessary to unify support, as has been well described by John Thompson (1995) when he illustrates the tools through which ideology works. It is no surprise that populism emerges in times of crisis: in such cases, allegedly inept and corrupt political leadership often becomes the first target of popular anger, in this way facilitating the conveyance of the populist message (Weyland, 1996).

Among the key figures shown in Table 3, we also highlight the constant call to Christian roots; this is almost exclusively present in right-wing populism. The religious argument is nevertheless used in conjunction with the idea of defending national sovereignty and/or opposing to the "invasion of migrants". ${ }^{18}$

Our study has taken into account, in Italy, four parties (Partito Democratico-Democratic Party, Forza Italia-Go Italy!, Lega NordNorth League and Movimento Cinque Stelle-Five Star Movement) and their leaders (Matteo Renzi, Silvio Berlusconi, Matteo Salvini and Beppe Grillo ${ }^{19}$ ). We have not found elements of "social 
populism" in these political actors; some elements of this form of populism seem to be present in some radical left-wing formations and even in new civic aggregations: however, they have not been studied and will be the subject of subsequent research work. ${ }^{20}$

Among the four types of populisms, a special short analysis is dedicated to technopopulism, which derives from the correlation of populism, technocracy and the rising importance of digital communication (De Blasio, 2014; Marres, 2017).

\section{Technopopulism}

Among the four types of populism we have defined, technopopulism represents a major emerging innovation, although the relationship between populism and technology is not new in the European political scene. Some commentators have suggested that the old opposition between left and right has been replaced by the "cleavage" between populism and technocracy (Ferguson 2015). We believe that the question should be framed in another way, considering from one side the opposition between technocracy and techno-libertarianism and from the other side, the relationship between populism and technocracy. "Technocracy holds that there is only one correct policy solution; populism holds that there is only one authentic will of the people" (Müller, 2017). This means that both technocracy and populism are, in a certain way, apolitical and ready to reject democratic debate.

Alongside the traditional semantic oppositions in which populism lives and from which it is fed (true people vs. élites), new "social storytelling" has emerged in recent years. Surely one of the most interesting stories is that of the opposition between technocracy (mostly associated with European institutions, albeit not exclusively) and techno-libertarianism, often associated with the extensive use of digital technology and with the Internet as an open and accessible space. The latter, simultaneously features the modernity of youth and the opportunity (coming mainly from democratic participation platforms) to develop a "real" direct democracy at low cost and without party interference. The Europe of technocrats-as it is spuriously defined-is constantly present in the political manifestos of the North League, the Five Star Movement and even in the speeches of the Democratic Party leader-Matteo Renzi-who was also Prime Minister for 3 years. Technocracy can be traced back to a number of problems: from the sentimental disconnection between European institutions and citizens to the economic crisis. On the opposite side, the rhetoric on technological innovation and techno-libertarianism does not appear to fascinate the North League, but it is highly present both in the political metaphors of Matteo Renzi and in the centrality of online direct democracy as proposed by the Five Star Movement $^{21}$

We agree with Bickerton and Invernizzi Accetti (2017) when they write that "far from being political opposites (or even correctives) for one another, populism and technocracy can only be understood-and therefore approached-together, as parallel expression of the same underlying set of phenomena" (Bickerton and Invernizzi Accetti, 2017, p 327).

The ostentation of advanced technology tools, the use of technological metaphors, and the centrality of social media in the relationship with citizens are some of the most obvious elements in the public speeches of the Democratic Party leader. Beppe Grillo, by contrast, prefers to flaunt his movement's platform of direct democracy, often referred to it as a sort of quasi-alternative instrument to parliament (despite its being only open to party members). ${ }^{22}$

The rhetoric of digital technologies for participation has been highly present in Italian politics over the last few years, and it has been de facto legitimised by the new centrality assumed by the public participation platforms used by the state to promote open government. ${ }^{23}$ From this perspective, we must remember that one of the rhetorical arguments accompanying the advance of neoliberalism ${ }^{24}$ found its strong points in two keywords: 1) quantity and 2) efficiency.

The concept of quantity is closely linked to that of "accumulation" but, unlike the latter, it does not only involve the economic sphere. In fact, it relates to the need for a wide range of services or, rather, an ample quantity of services, although this is actually just in theory. The concept of efficiency, however, is often defined through its temporal dimension; according to this definition, an efficient state would be one in which there is a very short reaction time between making policy proposals and carrying them out. In short, an efficient state has rapid, effective decision-making procedures that are legitimised by the spectacular rules of the socalled "audience democracies" (Manin 1995). An efficient state therefore requires a strong executive at the centre and has no need for the red tape of parliamentary procedures: this leads to the idea that parliaments should reduce their competencies (or perhaps even disappear or be replaced by more "lightweight" institutions). Here, we find some of the linkages between technopopulist rhetoric and neo-liberal populism (in which some traces of techno-libertarianism are present).

These two aspects are very often present in the discourses and programmatic documents of both the Five Star Movement and the Democratic Party; they seem to find a point of contact in "surrogate representation" (Mansbridge, 2003, 2011), which is also a "tool" to facilitate the institutionalisation of neo-populist parties.

Then, technopopulism can at least be defined as "the belief that the 'government of the people, by the people, for the people' (Lincoln, 1953 [1863]) is achievable by means of information communications technology. The term "belief" denotes here an ideology, not in the Marxian sense of a false consciousness but in the Althusserian sense of a set of ideas that have a material existence (Althusser, 1971). Technopopulism can also be understood in Foucauldian terms as an emerging discourse (Foucault, 1972), "that is, as a body of knowledge, norms, attitudes, and practices that arise from the hybridisation of two pre-existing discourses: populism and techno-libertarianism" (Deseriis, 2017, p 441). ${ }^{25}$ The issue of technopopulist parties can be further explored with the use of various empirical tools. At the same time, however, if we consider technopopulism as an emerging discourse or a "discursive ideology," we should also consider the possibility of finding elements and dimensions of technopopulism even in parties not clearly definable as "techno-parties". What is obvious, however, is that both technopopulism and technocratic approaches in neo-liberal populism find common ground in considering technology as a framework and not as a tool. This commonality is a further element that confirms the distance between new emerging populisms and the practices of deliberative and participatory democracy.

Our analysis also suggests that technopopulism can be considered to be one the basic elements of the new trends of depoliticisation (Hay, 2007, 2014; Fawcett et al., 2017). At the same time, hyper-representation, favouring an anti-pluralist wave, constitutes another important tool for depoliticisation processes. If social populism - in Laclau's (2005) perspective-can represent a counter-depoliticisation tool, technopopulism constitutes a way to strengthen the depoliticisation process of Western democracies.

Received: 6 October 2017 Accepted: 17 January 2018 Published online: 13 February 2018 


\section{Notes}

1 Populism often arises at times of crisis, and this trend is strongly linked with national identity. This is true in the Italian case as well. In this context, the nation and the state are separated, with the nation being held in higher esteem than the state. The use of national symbols in the linguistic and visual representation of populism highlights this situation (in this regard, consider the concept of "national-popular" as stated by Antonio Gramsci; see Forgacs, 1999, pp 363-370). In this article, however, we avoid discussing this important topic, which deserves a deeper analysis.

2 Usually, populism is defined using the idea of an antagonistic relationship between 'the people' and 'the elite' (Canovan, 1981; 1999; 2002; Laclau, 1979; 2005; Mény and Surel, 2002a; Mudde, 2004; Taggart, 2000). This idea requires the pre-conception that people should be conceived as characterised by homogeneous unity. Following this theoretical background, Cas Mudde has defined populism as a "thin-centred" ideology. Abts and Rummens (2007, p 407) propose another definition (or at least not contrasting with Mudde's): "in order to provide the most concise definition possible, we offer to define populism more frugally as a thin-centred ideology which advocates the sovereign rule of the people as a homogeneous body". Abts and Rummes also propose differentiating between the "popular appeals" of some political parties and populist political parties. We fully agree with this cultural position; regardless, it is very difficult-from an empirical perspective- to clearly identify populist parties. In many cases, in fact, the personalisation of politics gives us populist leaders even in political parties with a high level of presence within institutions. Alongside the governmental anti-politics, we should also study the many forms of governmental populism.

3 According to Francesco Raniolo (2013), political parties have five salient dimensions: (a) the competitive dimension, which is namely the search for votes to obtain public office; (b) the teleological dimension, that is, the action aimed at achieving specific objectives; (c) the sociological dimension, as the parties reflect the cleavages that cross a society; (d) the organisational dimension, since parties have continuity over time, internal articulation and territorial rooting; and (e) the institutional dimension, since they exist only within a rational legal order. If parties do not have the capacity to redefine themselves along the new social cleavages, it becomes impossible for them to build a connection with the people they should represent.

4 A concise and useful overview of the concept of populism (and of the state of the art in social and political science) is in Rovira Kaltwasser et al. (2017).

5 The "hypertrophy of popular sovereignty" (Bickerton and Invernizzi Accetti, 2017, p 337)

6 Also within the mainstream parties, we can easily observe some populist transformations (Mair, 2002). For this reason, we have considered in our analysis both Forza Italia (Go Italy!) and the Partito Democratico (the Democratic Party) with their controversial leaders, Silvio Berlusconi and Matteo Renzi. A brilliant analysis of the Democratic Party as the "last traditional party" can be read in Natale and Fasano (2017).

7 Discussing his theory of populism, Cas Mudde observes that there is essentially one constant to consider: a simplistic division of society in two opposing factions. Populism must therefore be defined as an ideology, which leads to a singular, confusing issue. For Mudde, populism is "an ideology that considers society to be ultimately separated into two homogeneous and antagonistic groups, 'the pure people' vs. 'the corrupt elite', and which argues that politics should be an expression of the volonté générale (general will) of the people". (Mudde, 2004, p 543) Elaborating upon his definition, he concludes that populism is a "thin-centred" ideology, meaning an ideology defined by a limited number of core political concepts. Thus, it can be easily combined with either similar or more complex ideologies, such as socialism or nationalism. The core concept of populism is then the existence of "the people" and, therefore, of an evil "elite" as well (oligarchy, or the Italian term, "casta" define a small group of privileged people who have power and money; in its semantic explosion, the term "casta" can also define all members of the "not-people").

8 A further part of our research-not presented here-comprises the study of political parties' policy proposals. Their impact has been assessed using an original approach to policy analysis (Lasswell, 1971; Cotta, della Porta and Morlino, 2008).

9 "In Italy, the language of the financial crisis uses the lexicon of newism, which does not mean it uses new words but that it upturns the content of old words: an enantiosemic lexicon in which a word is used to designate its opposite" (Cedroni, 2010, p 45).

10 The term "caste" is suddenly being used everywhere in journalism and in Italian politics to emphasise the separateness (and privilege) of "professional politicians".

11 Some authors see the same characteristics in the Argentinean movement of the descamisados (and in Peronism, more generally) and even in the Fascist rhetoric of the "combatant" (who is part of the populace) who opposes a "non-populace" of cowardly and disloyal people (whom Fascist rhetoric obviously equates with the Democratic opposition). On these topics see Ionescu and Gellner, 1969; Weyland, 1999.

12 See the anti-intellectual statements of Donald Trump (Leonid Bershkidky on Chicago Tribune of 14 November 2016: http://www.chicagotribune.com/news/opinion/ commentary/ct-donald-trump-revolution-elites-intellectuals-20161114-story.html).

13 "Do you imagine the Christian Democrats could have won the day on 18 April if they hadn't had a moral strength, a guiding concept, that is worth much more than all the so-called culture (culturame) of some people?"
14 The term "leaderism" refers to emphasis on the role of the political leader. Leaderism is the over-estimated centrality of the leader. Leaderism is an emerging discourse (in Foucauldian terms) and is often one of the drivers of a political party's presidentialisation process. See Higgins, 2012; Mazzoleni, 2012; Papadopoulos, 2013

15 This study has been recently expanded to other variables, such as the policy documents proposed by the political parties in four policy areas (family and welfare, security, citizenship, Europe) to compare the policy proposals with the propaganda rhetoric. All of this research is still in process because it is part of a two-year project on populism and democracy.

16 The idea of a "democratic" populism derives from Ernesto Laclau's influential studies on populism and democracy. Laclau (1977) argues that populism can be "articulated" with any position on the political spectrum, with the rhetoric adapted to accommodate shifts in political doctrine. This bottom-up adaptability can also be considered very close (also if from a different political perspective) to the peopledriven adaptability for government typical of the authoritarian populism expressed by, for example, Margaret Thatcher (Hall, 1985; Higgins, 2013).

17 Radical left is an ambiguous term because it designates both Marxist/post-Marxist parties and new political forces such as Podemos. The semantic meaning of the expression can also vary in different geographic contexts: some Italian politicians, for example, consider Jeremy Corbyn (leader of the British Labour Party) to be a "radical leftist".

18 The claim for religion and the religious aspects of everyday life are important elements of some populisms. Some religious communities are backing some of the new populisms, others are exercising their prophetic office, and still other religious communities are trying to maintain a sort of neutrality. Nadia Marzouki, Duncan McDonnell, and Olivier Roy (2016) stated that there is an important distinction to be drawn between the churches and the populist movements. In fact, populists speak of identity and churches speak of faith. Regardless, religious (or presumed religious) backgrounds are also present in some new populist political parties. We have decided to not deepen this topic both due to its complexity and its irrelevance in the scenario illustrated by our analysis in this context.

19 Beppe Grillo, a former comedian, is the founder and inspirational leader of M5S; he presents a figure that is different from the others. Nonetheless, he can be considered an authoritative and influential leader of the -party.

20 Some elements of social/democratic populism can be found in the Spanish political party Podemos. Podemos is sometimes associated with the Italian Five Star Movement; it can be useful to underline that many differences exist between the two political aggregations. The first difference concerns the specific constituencies of the two parties (Segatti and Capuzzi, 2016); the second involves internal organisation and the policy proposal process; a third difference concerns political assets: while Podemos is definitely an anti-establishment party, the Five Star Movement play a political role in the interstitial space between the anti-establishment approach and a radical anti-system position. The Five Star Movement presents, in fact, a double-faced identity; from one side, the environmentalist background of the old grouping while from the other, a personal populist party, with a boss who controls the parliamentary group and the representatives in elective assemblies and who is the facilitator of the break with the traditional political establishment. The stratarchical organisation (Bardi et al., 2014) of the Five-Star Movement contributes to empowering the role of the charismatic leader as the hyper-representative of the "true people" struggling with the "non-people".

21 The latest generation of "technopopulist parties" includes the Five Star Movement in Italy, Podemos in Spain, and the Pirate Party in Iceland (and, more generally, the different Pirate Parties across Europe). There are some important and peculiar differences among these parties (Damiani and Viviani 2018; Deseriis, 2017). In our opinion, Podemos and the Icelandic Pirate Party can surely be defined as technoparties, but they cannot be completely framed into technopopulism, basically because they do not use technological tools to expand the phenomenon of hyperrepresentation. At the same time, these two parties tend to exclude-in their internal organisations as well-plebiscitary-style drifts.

22 The idea of a direct democracy achieved through participatory democracy software (such as Liquid Feedback and now with the proprietary platform Rousseau) has always been present in Beppe Grillo's speeches, and it has been one of the basic point of M5S' political programme from its origin. The myth of online direct democracy is an outcome of direct democracy (which is one of the measures proposed by populist parties to replace the "declining" representation system); usually, it is not connected with the idea of a deliberative e-democracy.

23 Honestly, we should also note that communication and digital media seem really to give new opportunities for political inclusion: from e-voting technicalities to the computerisation of organisational infrastructure and circuits of parliamentary decision-making and ultimately the creation of a new public sphere centred on discursive and participatory/deliberative practices. Technology, in other words, can also play a role in the renewal of the old mass parties (now often liquid and stratarchically presidentialised) and the new ones (caught between franchise models and genuinely participatory trends).

24 Here, we refer to neo-liberalism as it has been defined, among others, by Crouch (2003; 2011), della Porta (2013), and Streeck (2014). 
25 Marco Deseriis distinguishes between two variants of technopopulism: "a technocratic and leaderless variant, which pursues and enacts meritocratic forms of democratic participation; and a leaderist, more strictly populist, variant wherein charismatic leaders play a critical role in conferring unity and identity to their parties" (Deseriis, 2017, p 441).

\section{References}

Abts K, Rummens S (2007) Populism versus democracy. Political Stud 55:405-424 Albertazzi D, McDonnell D (eds) (2008) Twenty-first century populism the spectre of western European democracy. Palgrave Macmillan, Houndmills

Albertazzi D, McDonnell D (2015) Populists in power. Routledge, London

Albertazzi D, Mueller S (2013) Populism and liberal democracy: populists in government in Austria, Italy, Poland and Switzerland. Gov Oppos 48 (3):343-71

Althusser L (1971) Ideology and ideological state apparatus. In: Lenin and philosophy and other essays, Monthly Review Press, New York, pp 121-176 (translated by Ben Brewster)

Anastasia S, Anselmi M, Falcinelli D (2015) Populismo penale. Una prospettiva italiana. Cedam, Padova

Anselmi M (2017) Poulismo. Teorie e prassi. Mondadori, Milano

Bacqué MHet, Sintomer Y (eds) (2011) La démocratie participative. Histoire et généalogie. La Découverte, Paris

Bardi L, Bartolini S, Trechsel A (2014) Party adaptation and change and the crisis of democracy, in. Part Polit 20(15):151-159. https://doi.org/10.1177/ 1354068813519966

Betz H-G (2002) Conditions favouring the success and failure of radical right-wing populist parties in contemporary democracies. In: Meny Y, Surel Y (eds) Democracies and the populist challenge. Palgrave, Basingstoke

Bickerton C, Invernizzi Accetti C (2017) Populism and technocracy. In: Rovira Kaltwasser C, Taggart P, Ochoa Esejo P, Ostguy P (eds) The Oxford Handbook of Populism. Oxford University Press, Oxford

Canovan M (1981) Populism. Harcourt Brace Jovanovich, NewYork

Canovan M (1999) Trust the people! populism and the two faces of democracy. Political Stud 47(1):2-16

Canovan M (2002) Taking politics to the people: populism as the ideology of democracy. In: Mény Y, Surel Y (eds) Democracies and the populist challenge. Palgrave, New York, pp 25-44

Canovan M (2004) Populism for political theorists?. J Political Ideol 9(3):241-52

Cedroni L (2010) Il linguaggio politico della transizione. Tra populismo e anticultura. Armando, Roma

Cotta M, della Porta D, Morlino L (2008) Scienza politica. Il Mulino, Bologna

Crouch C (2003) Postdemocrazia. Roma-Bari: Laterza. In: Crouch C (ed) Postdemocracy, Polity, Cambridge

Crouch C (2011) The strange non-death of neoliberalism. Polity, Cambridge

Dahl R (1989) Democracy and its critics. Yale University, New Haven

Damiani M (2017) La sinistra radicale in Europa. Italia, Francia, Spagna, Germania. Donzelli, Roma

Damiani M, Viviani L (2018) Due partiti, due populismi: una comparazione tra Podemos e Movimento 5 Stelle.

De Blasio E (2014) Democrazia digitale. LUISS University Press, Roma

De Blasio E, Sorice M (2014) Radicals, rebels and maybe beyond. Social movements, women's leadership and the web 2.0 in the Italian political sphere, Roma, CMCS LUISS

De Blasio E, Sorice M (eds) (2016) Innovazione democratica: un'introduzione. LUISS University Press, Roma

della Porta D (2013) Can democracy be saved? Polity, Cambridge

della Porta D, Fernòndez J, Kouki H, Mosca L (2017) Movement parties against Austerity. Polity, Cambridge

Deseriis M (2017) Technopopulism: the emergence of a discursive formation. triplec: communication, capitalism and critique. Open Access J Glob Sustain Inf Soc 15(2):441-458

Dupuis-Déri F (2013) Démocratie: histoire politique d'un mot aux Etats-Unis et en France. Lux, Montreal

Fasano L, Natale P (2017) L'ultimo partito. 10 anni di Partito Democratico. Giappichelli, Torino

Fasano L, Panarari M, Sorice M (2016) Mass media e sfera pubblica. Verso la fine della rappresentanza? Fondazione Giangiacomo Feltrinelli, Milano

Fawcett P, Flinders M, Hay C, Wood. M (eds) (2017) Anti-politics, depoliticization, and governance. Oxford University Press, Oxford

Forgacs D ed (1999) The Antonio Gramsci Reader. Selected writings 1916-1935. Lawrence and Wishart, London

Foucault M (1972) The Archaeology of Knowledge. Routledge, London

Hall S (1985) Authoritarian populism: a reply. New Left Rev 151:115

Hay C (2007) Why We Hate Politics. Polity Press, Cambridge

Hay C (2014) Depoliticisation as process, governance as practice: what did the 'first wave' get wrong and do we need a 'second wave' to put it right? Policy Polit 42(2):293-311
Hermet G (2001) Les populisms dans le mond. Une histoire sociologique XIXeXXe siècle. Fayard, Paris

Higgins M (2012) Lo sviluppo del populismo. In De Blasio E, Hibberd M, Higgins M, Sorice M (eds) La leadership politica. Media e costruzione del consenso. Carocci, Roma, pp 11-62

Higgins M (2013) 5. Governmentality, populism and empowerment. Media, Political Particip Empower 8:58

Ionescu G, Gellner E (eds) (1969) Populism: its meaning and national characteristics. Palgrave-Macmillan, Basingstoke

Jagers J, Walgrave S (2007) Populism as political communication style: an empirical study of political parties' discourse in Belgium. Eur J Political Res 46:319-345

Kriesi H (2015) Populism. Concepts and conditions for its rise in Europe. Comun Polit 16:175-193

Kriesi H, Pappas TS (2015) European populism in the shadow of the great recession. ECPR Press, Colchester

Laclau E (1977) Politics and ideology in Marxist theory: Capitalism, fascism, populism, London, $\mathrm{Nlb}$

Laclau E (1979) Politics and Ideology in Marxist Theory. Verso, London

Laclau E (2005) On populist reason. Verso, London

Lasswell HD (1971) A pre-view of policy sciences. Elsevier publishing company, Amsterdam

Lincoln A (1953) [1863] Address delivered at the dedication of the cemetery at Gettysburg. In: Basler Roy P (ed) Collected Works of Abraham Lincoln. Vol. 7 Rutgers University Press, New Brunswick, NJ, p 18-23

Littler J (2013) Meritocracy as plutocracy: the marketising of 'equality' within neoliberalism. New Form 80-81:52-72. https://doi.org/10.3898/NewF.80/ 81.03.2013

Littler J (2018) Against meritocracy. culture. power and myths of mobility. Routledge, London

Madison J (1787) Federalist paper. http://press-pubs.Uchicago.edu/founders/ documents/vlch4s19.html. Accessed 17 Jan 2018

Mair P (2000) Partyless democracy. New Left Rev 2:21

Mair P (2002) Populist democracy vs party democracy. In Democracies and the populist challenge. Palgrave Macmillan, London, pp 81-98

Mair P (2009) Representative versus responsible government. In MPIfG, Working Paper 09/8. Köln: Max Planck Institute für Gesellschaftsforshung

Mair P, Mudde C (1998) The party family and its study. Annu Rev Political Sci 1 (1):211-229

Mansbridge J (2003) Rethinking representation. Am Political Sci Rev 97 (4):515-528

Mansbridge J (2011) Clarifying the concept of representation. Am Political Sci Rev 105(3):621-630

Marres N (2017) Digital sociology. Polity, Cambridge

Marzouki N, McDonnell D, Roy O (eds) (2016) Saving the People. How Populists Hijack Religion, Hurst and Company, London

Mastropaolo A (2000) Antipolitica. All'origine della crisi italiana. L'Ancora del Mediterraneo, Napoli

Mastropaolo A (2016) Rappresentanza, partiti, governance. In Sau R (ed) (a cura di) La Politica. Categorie in questione. Franco Angeli, Milano, p 209-219

Mazzoleni GP (2012) La comunicazione politica. Il Mulino, Bologna

Mazzoleni G, Sfardini A (2010) Politica pop. Da "Porta a porta" a "L'isola dei famosi", Bologna, Il Mulino

Mény Y, Surel Y (2002a) The constitutive ambiguity of populism. In: Mény Y, Surel Y (eds) Democracies and the populist challenge. Palgrave, New York, p 1-24

Mény Y, Surel Y (eds) (2002b) Democracies and the populist challenge. Palgrave, New York

Moffitt B, Tormey S (2014) Rethinking populism: politics, mediatisation and political style. Political Stud 62:381-397

Morlino L (2011) Changes for democracy. actors, structures, processes. Oxford University Press, Oxford

Mouffe C (2000) The democratic paradox. Verso, London

Mouffe C (2005a) On the political. Routledge, London

Mouffe C (2005b) The end of politics and the challenge of right-wing populism. In: Panizza F (ed) Populism and the mirror of democracy. Verso, London, p $50-71$

Mudde C (2000) In the name of the peasantry, the proletariat, and the people: populisms in Eastern Europe, in East European Politics and Societies, 15 (1):33-53

Mudde C (2004) The populist zeitgeist. Gov Oppos 39(4):541-63

Mudde C (2015) Populism in Europe: a primer. Open Democracy 12 (https://www. opendemocracy.net/caneurope-make-it/cas-mudde/populism-in-europeprimer; last accessed 17 Jan 2018)

Mudde C, Kaltwasser R (2013) Populism. In: Freeden M, Sargent LT, Stears M (eds) The oxford handbook of political Ideologies. Oxford University Press, Oxford

Müller J-W (2017) What is populism. Penguin Books, London 
Natale P, Fasano LM (2017) L'ultimo partito. 10 anni di Partito Democratico. Giappichelli, Torino

Panarari M (2010) L'egemonia sottoculturale. Torino, Einaudi

Papadopoulos Y (2013) Democracy in crisis? politics, governance and policy. Palgrave Macmillan, Basingstoke

Pateman C (1970) Participation and democratic theory. Cambridge: University Press, Cambridge

Pauwels T (2014) Populism in Western Europe: comparing Belgium, Germany and the Netherlands. Routledge, London

Raniolo F (2013) I partiti politici. Roma-Bari: Laterza

Revelli M (2017) Populismo 2.0. Einaudi, Torino

Rovira Kaltwasser C, Taggart P, Ochoa Esejo P, Ostguy P (2017) Populism. An overview of the concept and the state of the art. In: Rovira Kaltwasser C, Taggart P, Ochoa Esejo P, Ostguy P (eds) The Oxford handbook of Populism. Oxford University Press, Oxford, p 1-24

Saward M (2010) The representative claim. Oxford University Press, Oxford

Segatti P, Capuzzi F (2016) Five Stars Movement, Syriza and Podemos: A Mediterranean Model? Beyond Trump. Populism on the Rise, 47-72

Sintomer Y (2011) Petite histoire de l'expérimentation démocratique. Tirage au sort et politique d'Athènes à nos jours. La Découverte, Paris

Sorice M (2014) I media e la democrazia. Carocci, Roma

Stanley B (2008) The thin ideology of populism. J Political Ideol 13:95-110

Streeck W (2014) Buying time: the delayed crisis of democratic capitalism. Verso Books, London

Taggart P (2000) Populism. Open University Press, Philadelphia

Taguieff PA (1995) Political science confronts populism: from a conceptual mirage to a real problem. Telos 103:9-43

Taguieff PA (2002) L'illusion populiste. Berg International Éditeurs, Paris

Tarchi M (2002) Populism Italian style. In: Mény Y, Surel Y (eds) Democracies and the populist challenge. Palgrave, NewYork, p 120-38

Thompson JB (1995) The media and modernity: a social theory of the media. Stanford University Press, Stanford

Tormey S (2015) The end of representative politics. Polity, Cambridge

Urbinati N (1998) Democracy and populism. Constellations 5(1):110-24

Urbinati N (2013a) Democrazia in diretta. Le nuove sfide alla rappresentanza. Feltrinelli, Milano

Urbinati N (2013b) The populist phenomenon, Raisons politiques 2013/3 ( $\mathrm{N}^{\circ} 51$ ). 137-154, https://doi.org/10.3917/rai.051.0137

van Kessel S (2015) Populist parties in Europe. Agents of discontent? Palgrave, London

van Reybrouck D (2016) Against elections: The case for democracy. Penguin Random House, London
Weyland K (1996) Neopopulism and neoliberalism in Latin America: unexpected affinities. Stud Comp Int Dev 31(3):3-31

Weyland K (1999) Neoliberal populism in Latin America and eastern Europe, in Comparative Politics, pp 379-401

Weyland K (2001) Clarifying a contested concept-populism in the study of Latin American politics. Comp Polit 34:1-22

Woods D (2014) The many faces of populism: diverse but not disparate. Res Political Sociol 22:1-26

\section{Data availability}

The datasets analysed during the current study are available in the Open Democracy website: http://opendemocracy.it/conflict-and-participation/populisms/

\section{Additional information}

Competing interests: The authors declare no competing financial interests.

Reprints and permission information is available online at http://www.nature.com/ reprints

Publisher's note: Springer Nature remains neutral with regard to jurisdictional claims in published maps and institutional affiliations.

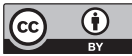

Open Access This article is licensed under a Creative Commons Attribution 4.0 International License, which permits use, sharing, adaptation, distribution and reproduction in any medium or format, as long as you give appropriate credit to the original author(s) and the source, provide a link to the Creative Commons license, and indicate if changes were made. The images or other third party material in this article are included in the article's Creative Commons license, unless indicated otherwise in a credit line to the material. If material is not included in the article's Creative Commons license and your intended use is not permitted by statutory regulation or exceeds the permitted use, you will need to obtain permission directly from the copyright holder. To view a copy of this license, visit http://creativecommons.org/ licenses/by/4.0/.

(C) The Author(s) 2018 